\title{
İşte var olamama bağlamında örgütsel sinizmin tükenmişlik üzerine etkisi: Atatürk Üniversitesi HELİTAM örneği*
} The effect of organizational cyncism on burnout in the context
of presenteeism: Atatürk University HELITAM example

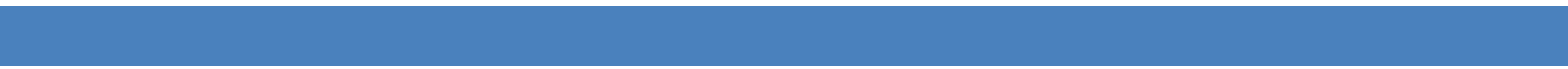

\author{
Elif Alar Erkal $^{1}$ (iD) Atılhan Naktiyok ${ }^{2}$ (D) \\ 1 Öğr.Gör.Dr., Ağrı Üniversitesi, Meslek Yüksekokulu, İșletme Yönetimi, Türkiye, e-mail: eaerkal@agri.edu.tr
}

2 Prof.Dr., Atatürk Üniversitesi, İktisadi ve İdari Bilimler Fakültesi, İşletme Bölümü, Türkiye, e-mail: anakti@atauni.edu.tr

Öz

Hemşirelerin iş ortamındaki tutumlarının incelenmesi sadece kendileri üzerindeki etkileri değil aynı zamanda yaptıkları işin gereği olarak hastalar ve genel olarak hastanede sunulan sağlık hizmetlerinin etkilerinin ortaya konulması açısından önemlidir. Bu çalışmanın amacı hemşirelerin örgütsel sinizm, tükenmişlik ve işte var olamama tutumları arasındaki ilişkiyi ve bunlarla ilişkili diğer faktörleri ortaya koymaktır. Bu amaçla Atatürk Üniversitesi Hemşirelik Lisans Tamamlama (HELITAM) programında öğrenim gören 567 hemşireye anket yapılmış, 364 hemşireden geri dönüş sağlanmıştır. Yapısal eşitlik yönteminin kullanıldığı çalışmada veriler demografik, örgütsel sinizm, tükenmişlik ve işte var olamama soruların yer aldığı anket tekniğiyle elde edilmiştir. Çalışmada anket ile toplanan veriler SPSS ve AMOS istatistik paket programları aracılığıyla analiz edilmiştir. Doğrulayıcı faktör analizi (DFA) ile anketlerin güvenilirliği ve geçerliliği test edilmiştir. korelasyon ve yapısal eşitlik modeli kullanılarak çalışmada oluşturulan hipotezler test edilerek elde edilen bulgular yorumlanmıştır. Analizin diğer bulgularına göre, örgütsel sinizm ile duygusal tükenmişlik, kişisel başarı ve duyarsızlaşma arasındaki ilişkide işte var olamama sorunu aracı rol oynamaktadır. Sonuç olarak örgütsel sinizm, tükenmişlik ve işte var olamama tutumları arasındaki ilişkiyi inceleyen bu çalı̧̧mada hemşirelerin sinizm düzeyi arttıkça tükenmişlik düzeylerinin de önemli düzeyde arttığı görülmüştür. Sinizmin duygusal tükenmişliğe, kişisel başarının düşmesine ve zamanla hayata karşı duyarsız davranışların ortaya çıkmasına neden olduğu belirlenmiştir.

Anahtar kelimeler: Örgütsel sinizm, tükenmişlik, işte var olamama, yapısal eşitlik modeli.

JEL kodları: M10, C12

\section{Abstract}

Examining the attitudes of nurses in the work environment is important not only in terms of their effects on themselves, but also in terms of revealing the effects of the patients and the health services provided in the hospital in general as a requirement of their work. The aim of this study is to reveal the relationship between nurses' organizational cynicism, burnout and presenteeism attitudes and other factors associated with them. For this purpose, 567 nurses studying in Atatürk University Nursing Undergraduate Completion Program (HELITAM) were surveyed, and 364 nurses gave

"Bu makale Elif Alar Erkal'ın "İşte var olamama bağlamında örgütsel sinizmin tükenmişlik üzerine etkisi: Atatürk Üniversitesi HELİTAM örneği" adlı doktora tezinden türetilmiştir.

Citation/Atıf: ALAR ERKAL, E. \& NAKTIYOK, A., (2021). İşte var olamama bağlamında örgütsel sinizmin tükenmişlik üzerine etkisi: Atatürk Üniversitesi HELITTAM örneği. Journal of Life Economics. 8(4): 443-454, DOI: 10.15637/jlecon.8.4.04 
feedback. In the study, in which the structural equation method was used, the data were obtained by the questionnaire technique, which included demographic, organizational cynicism, burnout and presenteeism questions. The obtained data were analyzed using SPSS and AMOS programs. Confirmatory factor analysis (CFA) was used to test the reliability and validity of the questionnaires used in the research. In the study, the hypotheses created to reach the goal were tested with the correlation and structural equation model, and the results were interpreted in this direction. According to other findings obtained from the analysis, the problem of presenteeism plays a mediating role in the relationship between organizational cynicism and emotional burnout, personal success and depersonalization. As a result, in this study examining the relationship between organizational cynicism, burnout and presenteeism attitudes, it was observed that as the cynicism level of nurses increased, their burnout level increased significantly. It has been determined that cynicism causes emotional exhaustion, a decrease in personal success, and the emergence of insensitive behaviors towards life over time.

Keywords: Organizational cynicism, burnout, presenteeism, structurel equation model.

JEL codes: M10, C12

\section{GİRIŞ}

Sosyal bir varlık olan insanın örgütler açısından önemi açıktır. Bu nedenle örgütlerin çalışanlarına karşı olumlu davranışlarda bulunması günümüz dünyasında önem arz etmektedir. Hızla gelişen teknoloji, küreselleşme ve örgüt ortamındaki değişimler neticesinde yöneticilerin davranış şekillerinde birçok olumsuz tutum görülmektedir. Bu olumsuz tutumlardan baz1ları örgütsel sinizm, tükenmişlik ve işte var olamamadır. Örgütsel sinizm çalışanların örgüte olan bağlılık duygusunu, performansını ve verimliliğini azaltan duygu, değer, inanç ve davranışlardan oluşmaktadır. Örgütsel sinizmin benzeri bir diğer kavram ise tükenmişliktir. Tükenmişlik, yavaş ve aralıksız seyreden bir hastalık gibi kişiyi bir girdaba sürükleyen davranış biçimidir. Birey sinizm yaşayarak tükenirken, aynı zamanda dolaylı olarak işte var olamama mücadelesi ile karşı karşıya kalabilmektedir. İşte var olamama neticesinde bireyler fiziksel olarak iş ortamında bulunsalar da yaşadıkları sorunlar nedeniyle kendilerini işlerine tam olarak verememekte ve kapasitelerini tam olarak kullanamamaktadır.

Hemşirelik, diğer sağlık çalışanlarında olduğu gibi yoğun mesai saatleri altında çalışmayı ve bunun yanı sıra hastalık ya da kendini iyi hissetmeme koşulları altında dahi işe gitmeyi gerektiren, fedakârlık gerektiren bir meslektir. Bu nedenle de diğer mesleklere göre daha zordur (Brobrovic, H., Brborovic, O., Brumen, Pavlekovic ve Mustajbegovic, 2014). Stevens (2004)'a göre, hemşirelik mesleğinin daha çok kadınlar tarafından sürdürülüyor olması ve kadınların mesleki sorumluluklarının yanı sıra aile içerisinde annelik ve çocuk bakımı gibi rollerinin de olması tükenmişlik düzeylerinin artmasına sebebiyet vermektedir. İş ve günlük hayatlarında birden fazla rolü üstlenen hemşireler iş performanslarında düşüş yaşarken diğer yandan iş arkadaşlarının performanslarını da olumsuz yönde etkilemektedir (Yavan, 2017: 250).
Çalışmada hemşirelerin çalıştıkları ortamda yaşadıkları örgütsel sinizmin üzerlerinde yarattığı duygusal tükenmenin derecesi, kişisel başarı hislerindeki azalma ve yaşadıkları duyarsızlaşmanın incelenmesi amaçlanmaktadır. Ayrıca işte var olamama sorunun örgütsel sinizmin tükenmişliğe sebep olması üzerindeki rolü araştırılmıştır.

Şimdiye kadar örgütsel sinizm, tükenmişlik ve işte var olamama kavramları birçok çalışmada konu edinilmesine rağmen söz konusu çalışmalarda daha çok kavramlar arasındaki ikili ilişkiler üzerinde durulmuştur. Bu çalışma, örgütsel sinizmin tükenmişlik üzerine etkisinde işte var olamamanın nasıl bir rol oynadığını belirlemesi bakımından diğer çalışmalardan farklılaşmakta ve bu konuda literatürdeki uygulamalı çalışma eksikliğini gidermektedir.

\section{2. ÖRGÜTSEL SIINIZM}

Örgütsel sinizm nesnelerle ilişkilendirilen ve deneyimler sonucunda öğrenilebilen bir inançtır. James (2005: 7) örgütsel sinizmi, bireyin olumsuz duygu ve davranışları sonucuna şekillenen, çevrenin etkisiyle değişikliğe uğratılabilen sosyal ve bireysel deneyimler olarak tanımlamıştır. Konuyla ilgili birçok tanımlama bulunmasına karşın, Vance örgütsel sinizmin iki boyutuna dikkat çekmektedir. Bunlar; kişinin kendi hatalarının negatif davranışları artırması ve tüm bunlara rağmen örgütün gelişme göstermesidir (Brandes, 1997: 18).

Dean ve diğ. (1998:345)'e göre örgütsel sinizm; beklenti, atfetme, sosyal değişin, duygusal olaylar ve sosyal güdülenme kuramları olarak tanımlanmaktadır. Konuyla ilgili olarak çalışma yapan birçok araştırmacı sinizmin kişilere, örgütlere, mesleklere ve örgütteki üst yönetime dikkat çekmektedir. Sinizm kavramının anlaşılabilir hale gelmesi, eylemleştirilmesi ve sağlam bir yapı oluşturulabilmesi amacıyla sinizmi oluşturan 
temel kuramlar bir araya getirilerek yeni bir sinizm kavramı geliştirilmeye çalışılmıştır (Kalağan, 2009: 3839).

\section{TÜKENMIŞLIK}

Tükenmişlik bireyin hayatıyla ilgili olarak tükenme hissetmesi, geleceğe dair ümitlerini kaybetmesi ve bunun sonucunda duygusal açıdan yıpranmasını ifade etmektedir. Tükenmişlik gerçekten uzak beklenti ve umutları arasındaki dengesiz denklemin ortaya çıkması ile gelişir (Gürbüz ve Bayramlı, 2005: 143). Tükenmişlik yavaş ve aralıksız olarak devam eden bir hastalık gibi bireyin ruhsal kayıplar yaşamasına ve manevi değerlerini yitirmesine neden olur (Maslach ve Leiter, 1997: 17). Tükenmişlikle ilgili ilk çalışmalar Freudenberger tarafından yapılmış ve çalışanın performansında başarısızlığa, çeşitli kaynakların tükenmesine yol açtığı şeklinde tanımlanmıştır. Konuyla ilgili olarak tükenmişliği Berns (1984)'te çalışanın işinden uzaklaşarak ilgisiz davranışlar göstermesi olarak, Pines ve Aronson (1988); tükenmişliğin uzun dönemde yaşanan fiziksel, duygusal ve zihinsel yorgunluk hali olarak tanımlamışlardır (Soysal, 2009: 290-309; Pines ve Aronson, 1988: 9-13). Sosyal bir psikolog olan Maslach ise konuyla ilgili olarak; tükenmişliğin araştırmacılar tarafından ilgi odağı olmadan çok daha öncesinde bir sorun olarak algılandığını belirtmiştir. Maslach duygusal stresi yönetmenin bireylerin işteki davranışlarının ve bireysel gelişimlerine katkısında oldukça önemli olduğunu fark etmiştir (Maslach vd., 2001: 399). Günümüzde en yaygın olan ve en sık kullanılan tükenmişlik modeli Christiana Maslach'ın geliştirdiği Maslach tükenmişlik envanteridir (Dalkılıç, 2006: 7). Bu modelde tükenmişlik 3 boyutlu bir sendrom olarak tanımlanmaktadır. Aşağıda tükenmişlik boyutları ve bu boyutlara ait özelliklerden bahsedilmiştir.

\subsection{Duygusal Tükenme}

Duygusal tükenme; zihnin yorulması, kişinin enerjisinin tükenmesi, mutsuz olma, isteksizlik duyma, umutsuz hissetme kavramlarından oluşmaktadır. Bu duyguları yoğun olarak hisseden bireyler kendilerini çevrelerine karşı negatif yüklerle yüklenmiş hissederler (Yıldız, 2015: 61). Duygusal tükenen kişiler zamanla bütün enerjilerinin bittiğini hissederek zamanla etrafındaki insanlarla ilişkiyi keser yani fiziksel olarak da tükenirler. Duygusal tükenme stres karşısında verilen ilk tepki olarak kabul edilmektedir (Maslach ve Leiter, 1997: 17). Yapılan araştırmalarda bireyler en çok duygusal tükenmişlik yaşadığını söylemektedirler. Temel boyut duygusal tükenme gibi görünse de tükenmişliğin belirlenmesinde tek başına yeterli olmadığ1 söylenebilir (Dalkılıç, 2014: 65-66).

\subsection{Duyarsızlaşma}

Bu boyut kişilere yönelik sert, kaba, ilgisiz, insana yönelik olmayan davranışların bulunduğu, bireyin karşısındaki kişiye yönelik davranışlarını gösteren boyuttur (Maslach vd., 2001: 403, Baysal, 1995: 32, Yıldırım, 1996: 10). Geliştirilen bu soğuk ve katı tavırlar çeşitli şekillerde ortaya çıkmaktadır: Kişi karşısındakine kaba, aşağılayıcı, küçük düşürücü davranabilir, onların isteklerini karşılamaz ve insanları kafasında tek tip hale getirerek kalıplaştırabilir (Örmen, 1993: 2, Dalkılıç, 2004: 66). Duyarsızlaşan bireyler işine karşı ilgilerini azaltmaya başlarlar. Kişi duyarsızlaştığını fark ettikçe kendini bu girdaptan kurtarmaya çalışmaktadır. Bu boyutta kendi kişisel sorunlarını çözemeyecek kadar güçsüzleşen bireyler duygusal tükenmeden kaç1namadıklarından duyarsız davranmaya başlarlar. Duyarsızlaşma yaşayanlar diğerleriyle aralarına mesafe koyarak "duygusal tampon" oluştururlar. Kendini diğerlerinden üstün görmeye çalışarak karşısındakine eşya gibi davranmaya başlayan duyarsız bireyler tüm bu olumsuzluklar içinde zamanla daha fazla yıpranarak topluluk içinde silikleşmeye başlarlar (Maslach vd., 2001: 403, Yildırım, 1996: 10).

\subsection{Kişisel Başarının Azalması}

Kişisel başarının azalması boyutunda; bireyler yaşadıkları olaylar karşısında yetersizlik hissi, verimliliklerinde azalma, diğerleriyle çatışmalar yaşama, kendilerine olan özsaygılarında azalma gibi belirtiler gösterirler. Bu boyut zamanla kişilerin kendileri hakkında düşündükleri olumsuz değerlendirmelerin zamanla başka insanlar hakkındaki olumsuz düşüncelere dönüşmesine neden olmaktadır (Maslach vd., 2001: 403; Maslach ve Zimbardo, 1982: 5; Wright ve Bonett, 1998: 492; Cordes, Dougherty ve Blum, 1997: 686, Hock, 1988: 168). Yetersizlik hissi bireylerde yaptıkları işler ile ilgili başarısızlık duygusu yaratır, başarılı olunan işlerde ise anlamsızlık hissi yaratır. Yeteneklerine karşı güven duymayan bireyler yaşadığı her kötü olayın kendi başarısızlığından kaynaklandığına inanarak, değersizlik hissi duymaya başlarlar. Zamanla bütün bu duygular kendilerine olan inançlarını kaybetmelerine neden olmaktadır (Maslach ve Leiter, 1997: 18).

\section{DEĞISSKENLERE YÖNELIKK LITTERA- TÜR TARAMASI}

Beşeri kaynak olan insan örgütlerin sürdürülebilir rekabet avantajı sağlamasında en önemli unsurdur. İnsanın doğru yönetimi örgütlerin yaşamlarının devamında önemli bir faktördür. Etkili insan yönetiminde çalışanların fiziksel sağlıkları kadar psikolojik sağlıklarının da doğru yönetilmesi gerekmektedir. Örgütsel ortamın niteliği, yöneticilerin doğru yönetim biçimi örgütte çalışanların tutum ve davranışlarını etkile- 
mektedir. Bu tutum ve davranışlar çalışanların örgütteki davranışlarına olumlu ve olumsuz birçok durumun ortaya çıkmasına neden olmaktadır. Olumsuz davranışlardan örgütsel sinizm, tükenmişlik ve işte var olamama bu çalışmanın temel konusunu oluşturmaktadır. Ulusal ve uluslararası literatürde çalışmanın değişkenlerinin ve farklı birtakım değişkenlerin konu edildiği çalışmalar sonuçları üzerinden aşağıdaki gibi özetlenebilir:

2003 yılında Johnson ve O'Leary-Kelly'nin yaptığ 1 çalışmaya göre çalışanlar beklentilerinin karşılanmadığını anladıkları zaman hayal kırıklığına uğramış ve bu durum örgütsel sinizm ile duygusal tükenmişlik arasında bir ilişkinin varlığının ortaya çıkarmıştır (Johnson ve O'Leary-Kelly, 2003: 631). Üçok 2012 yılında kamu ve özel sektörde çalışan 203 kişiye yaptığı çalışmada örgütsel sinizm, psikolojik sözleşme ihlali ve tükenmişlik arasında anlamlı bir ilişki tespit etmiştir (Üçok, 2012: 77-138). 2014 yılında Tayvan'da 169 hemşireye Simha ve arkadaşları tarafından yapılan bir çalışmaya göre örgütsel sinizm ile tükenmişlik arasında pozitif yönlü bir ilişki tespit edilmiştir (Simha ve diğ., 2014: 482-504). Wei ve Wang (2015) 276 Çinli öğrenciye yaptıkları çalışmada örgütsel sinizmin duygusal tükenmişliği artırdığı ve yine örgütsel sinizmin duyarsızlaşmanın nedeni olduğu, kişisel başarı hissini ise azalttığı sonucuna ulaşmıştır (Wei ve Wang, 2015: 103-115). 2016 yılında Konya'da Eryeşil ve Öztürk tarafından sağlık çalışanlarına yapılan çalışmaya göre tükenmişliğin alt boyutları ve örgütsel sinizm arasında anlamlı ilişkiler tespit edilmiştir (Eryeşil ve Öztürk, 2016: 48-56). Konya Seydişehir Devlet Hastanesi çalışanlarına 2017 yılında yapılan bir çalışmada örgütsel sinizmin çalışanların tükenmişlik düzeylerine etkisi olduğu sonucuna ulaşılmıştır (İncesu, Yorulmaz ve Evirgen, 2017: 370). Balcı'nın 2016 yılında İstanbul'da öğretmenler üzerinde yaptığı çalışmada işte var olamama ile örgütsel sinizm arasında aynı yönlü bir ilişki tespit edilmiştir (Balcı, 2016: 1). 2018 yılında Bölür tarafından mobilya ve plastik işletmelerine yapılan bir çalışmada liderlik tarzları, örgütsel sinizm ve işte var olamama arasında anlamlı bir ilişkinin var olduğu tespit edilmiştir (Bölür, 2018: 1). Köse 2019 yılında 3 vakıf üniversitesindeki idari personele yaptığı çalışmada iş güvencesini kaybetme durumundan kaynaklı yaşanan işte var olamama ile çalışan tükenmişliğinin arttı̆̆ 1 yönünde ilişkinin varlığını tespit etmiştir (Köse, 2019: 46). 2016 yılında Zengin ve Kaygın Kars Sosyal Güvenlik Kurumu'ndaki 47 çalışan üzerinde yaptıkları anketle tükenmişliğin duyarsızlaşma boyutu ile işte var olamama arasında pozitif yönlü bir ilişki tespit etmiştir (Zengin ve Kaygın, 2016: 498). Munir ve arkadaşlarının İngiltere'de çeşitli kuruluşlara yaptıkları çalışmada çalışanların kendilerini kötü hissettikleri halde işlerinde olmaya çalıştıkları zamanlarda çalışma kapasitelerinde düşme, daha fazla stres yaşama ve işlerine karşı memnuniyetsizlik ortaya çıtığ tespit edilmiştir (Munir, Yarker, Haslam, 2008: 1461). Schaufeli ve arkadaşlarının 2009 yılındaki çalışma çalışmaya olan bağlılıkları gereği işte var olamama davranışı gösteren kişilerin daha fazla tükendikleri ve bu nedenle yaptıkları işten daha az memnuniyet duydukları tespit edilmiştir (Demerouti, Blanc, Bakker, Schaufeli, Hox, 2009: 62). Ferreira ve Martinez (2012) Portekiz'de 281 ilkokul öğretmenine yaptıkları çalışmada kişisel özelliklerin dışında işte var olamamanın da tükenmişliğe yol açtığı sonucuna ulaşmıştır (Martinez, F., Ferreira, 2012: 4380).

\section{ARAŞTIRMANIN YÖNTEMİ}

\subsection{Araştırmanın Amacı ve Önemi}

Araştırmanın temel amacı hemşirelerin örgütlerinde maruz kaldıkları örgütsel sinizmin yaşadıkları tükenmişliğe etkisinde işte var olamama sorunlarının belirlenmesidir. Örgütsel sinizm çalışanı örgütüne soğutan, performansını azaltan olumsuz bir davranış biçimidir. Örgütsel sinizmin benzeri bir kavram ise tükenmişliktir. Örgütte yaşanan olumsuz durumların bir sonucu olan tükenmişlik, kişinin duygusal olarak yıpranmasına, karşısındaki kişilere karşı alaycı, küçümseyici tavırlar sergilemesine neden olmaktadır. Tüm bu durumlar bireylerin örgütlerine karşı soğumasına neden olmaktadır. Bu iki kavram birbirini doğrudan etkilemenin dışında dolaylı olarak yeni durumların doğmasına da neden olabilmektedir. İște var olamama da örgütlerde görülen olumsuz bir diğer durum olarak karşımıza çıkmaktadır. İşte var olamayan bireyler fiziken işlerinde bulunsalar bile ruhen kendilerini işlerine verememektedirler.

\subsection{Araștırmanın Evreni ve Örneklem Tespiti}

Çalışmanın evrenini Atatürk Üniversitesi HELITTAM programında öğrenim gören 567 hemşire oluşturmaktadır. Örneklem büyüklüğü araştırma evreninden \%95'lik güvenilirlik \%5'lik hata payı ile 229 olarak hesaplanmıştır (https://www.surveysystem.com/sscalc. htm).

Şubat-Mart 2018 tarihleri arasındaki bir aylık süreçte, belirlenen örneklem grubuna anketler internet ortamında yapılmıştır. Yoğun çalışma şartları göz önünde bulundurulduğunda geri dönüş oranının az olabileceği ve cevaplardaki olası hatalar hesaba katılarak anketler tüm hemşirelere gönderilmiştir. 364 hemşireden geri dönüş sağlanmıştır.

\subsection{Araştırmanın Modeli ve Hipotezleri}

Günümüze kadar yapılan çalışmalarda örgütsel sinizm, tükenmişlik ve işte var olamama ile ilgili literatürde çeşitli araştırmalar bulunduğunu görmekteyiz. Sinizm ve tükenmişlik arasındaki ilişkiyi inceleyen çalışmalarda bu iki tutumun iç içe geçmiş olduğu ortaya 
koyulmaktadır. İnsan ilişkilerinin fazla olduğu mesleklerde tükenmişliğin daha yoğun olduğu bunun bir sinizm sendromu olduğu görülmektedir (Akhigbe ve Gail, 2017: 125; Maslach ve Jackson, 1981: 99 ). Örgütsel sinizmve tükenmişlik belirgin bir ilişkinin varlığını ortaya koyan çokça çalışma bulunmaktadır (Johnson ve O'Leary-Kelly, 2003: 631, Üçok, 2012: 77-138, Alan ve Fidanboy, 2013,165, Simha ve diğ., 2014: 482-504, Duru ve diğ., 2014: 1274-1284, Gün, 2015: 1-147, Wei ve Wang, 2015: 103-115, Özdemir ve Yaşar, 2016: 5061, Eryeşil ve Öztürk, 2016: 48-56; İncesu ve diğ., 2017: 370, Amasralı ve Aslan, 2017: 64, Akhigbe ve Gail, 2017: 125-140, İbrahimağaoğlu ve Can, 2017: 181, Bang ve Reio, 2017: 217-227). Örgütüne güvenini kaybeden çalışanlar zamanla hem çalıştıkları kuruma karşı hem de çalışma arkadaşlarına karşı sinik tutumlar geliştirmeye başlarlar. Bu durum işte var olamama sorunu ortaya çıkarmaktadır. Örgütsel sinizm ve işte var olamama arasındaki ilişkiyi destekleyen çalışmalar bulunmaktadır (Yıldırım, Saygın ve Uğuz: 2013, Özler ve Atalay: 2011, Balc1, 2016: 1, Bölür, 2018: 1). İşte var olamama sorunu yaşayan bireylerin fiziksel olarak işte olmalarına karşın performansları düşmekte ve tükenmişlik duygusu yaşamaktadırlar. Yapılan araştırmalar bu iki kavram arasındaki ilişkiyi destekler niteliktedir (Ricci ve Chee; 2005: 1228, Köse, 2019: 46, Sarıçam ve Çetintaş, 2015: 804, Zengin ve Kaygın, 2016: 498, Wright and Cropanzano, 1998;486-493, Munir ve diğ., 2008; 1461, Demerouti, Blanc, Bakker, Schaufeli, Hox, 2009:62, Demerouti ve diğ., 2009: 6, Demirbulat, Bozok; 2015: 4). Daha önce yapılan çalışmalarda örgütsel sinizmin tükenmişlik üzerine etkisinde işte var olamamanın rolünü ele alan çalışmaya rastlanılmamıştır. Sonuçların sunulması amacıyla araştırma sorusu belirlenmiş ve buna yönelik olarak kurulan model Şekil 1'de gösterilmiştir. Modele bağlamında araştırılacak hipotezler aşağıda yer almaktadır:

Araştırma Sorusu: Hemşirelerin örgütsel sinizm algılarının tükenmişlikleri üzerine olan etkisinde, yaşadıkları işte var olamama sorunu nasıl bir rol oynamaktadir?

Çalışma bağlamında yer alan kavramlara yönelik teorik açılamalar, oluşturulan model ve bu modelden yola çıkarak hazırlanan hipotezler aşağıda sunulmuştur:
H1: Örgütsel sinizm çalışanların tükenmişliklerini etkiler.

H1a:Örgütsel sinizm çalışanların duygusal tükenmişliklerini artırır.

H1b: Örgütsel sinizm çalışanların kişisel başarı hissini düşürür.

H1c: Örgütsel sinizm çalışanların duyarsızlaşmalarını artirir.

\section{H2: Örgütsel sinizm çalışanların işte var olamama} sorunlarını artırır.

H3:Çalışanların işte var olamama sorunları tükenmişliklerini etkiler.

H3a: Çalışanların işte var olamama sorunları duygusal tükenmişliklerini artırır.

H3b: Çalışanların işte var olamama sorunları kişisel başarı hislerini azaltır.

H3c: Çalışanların işte var olamama sorunları duyarsızlaşmalarını artırır.

H4: İşte var olamama sorunu örgütsel sinizm ile tükenmişlik arasındaki ilişkiyi etkiler.

H4a: Örgütsel sinizm ile duygusal tükenmişlik arasındaki ilişkide işte var olamama sorunu aracı rol oynar.

H4b: Örgütsel sinizm ile kişisel başarı hissi arasındaki ilişkide işte var olamama sorunu aracı rol oynar.

H4c: Örgütsel sinizm ile duyarsızlaşma hissi arasındaki ilişkide işte var olamama sorunu aracı rol oynar.

\subsection{Araştırmada Kullanılan Ölçekler}

Çalışmada hemşirelerin tükenmişlik seviyelerini ölçmek için Maslach (1981) tarafından geliştirilen tükenmişlik ölçeğinden yararlanılmıştır. Ölçek 3 boyutta toplam 22 sorudan oluşmaktadır. Ölçeğin boyutları duygusal tükenmişlik, kişisel başarı ve duyarsızlaşmadır. Anketteki ilk 9 ifade duygusal tükenmişliği, sonraki 8 ifade kişisel başarıyı ve son 5 ifade ise duyarsızlaşmayı ölçmek için kullanılmıştır. Çalışmanın katılımcıların çalıştıkları kurumda algıladıkları sinizmi ölçmek amacıyla Brandes vd. (1999) tarafından geliştirilen sinizm ölçeğinden yararlanılmıştır. Toplam 13 sorudan oluşan ölçek bilişsel, duyuşsal ve davranış-

Şekil 1. Araştırma Modeli

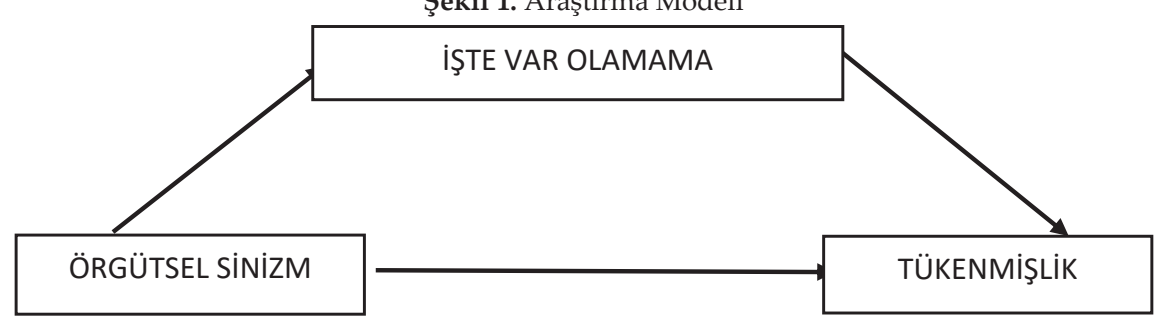


sal boyutlardan oluşmaktadır. Çalışmada çalışanların işte var olamama algılarını ölçmek amacıyla Mark \& Co Inc. in desteği ile Stanford Üniversitesi Tıp Fakültesinden Koopman vd. (1991) tarafından geliştirilen ve toplam 6 ifadeden oluşan Stanford Presenteizm Ölçeği (SPS-6) kullanılmıştır. Veri toplama aracı olarak kullanılan anketlerde 5'li Likert ölçeğinden yararlanılmiştır.

\subsection{Analiz Yöntemleri}

Araştırmaya ilişkin verilerin analiz edilebilmesi için SPSS ve AMOS paket programlarından yararlanılmıştır. Ölçeklerin geçerlilik ve güvenirliği ile ilgili olarak doğrulayıcı faktör analizi yapılmıştır. Doğrulayıcı faktör analizinde, korelasyon ve kovaryans matrislerinden faydalanılarak değişkenlerin kaç bağımsız grupta toplanılacağ ${ }_{1}$ ve elde edilen verilerin teoriyle ne kadar ölçüştüğü araştırılmaktadır (Şimşek, 2007: 7, Hair vd.,1998;112). Araştırma modelinin test edilebilmesi amacıyla modeldeki doğrudan ve dolaylı ilişkilerin belirlenmesi için yapısal eşitlik modellerinden yararlanılmıştır.

\subsection{Analiz ve Bulgular}

$\mathrm{Bu}$ bölümde çalışmada uygulanan anketlerde ele alınan hemşirelerin örgütsel sinizm, tükenmişlik ve işte var olamama ölçeklerine ilişkin güvenilirlik ve geçerlilik testleri sonuçlarına ve modelde yer alan değişkenleri doğrulayıcı faktör analizi bulguları yer almaktadir.

\subsubsection{Kullanılan Ölçeklerin Doğrulayıcı Faktör Analizi}

Çalışmamızda sinizmin bir bütün olarak tükenmişlik ve boyutlarına olan etkisine bakılacağından üç faktörlü sinizm ölçeği ikinci düzey faktör analizi yapılarak tek faktöre bağlanmıştır. Tek faktörlü yapıya ilişkin model test ve uyum indekslerinin kabul edilebilir s1nırlar içinde olduğu ve üç faktörlü yapıdan (birinci düzey doğrulayıcı faktör analizi modelinden) önemli ölçüde farklılık göstermediği görülmektedir. Gerçekleştirilen analiz neticesinde sinizm yapısını ifade eden model ve modele ait maddelerin faktör yükleri Şekil 2'de gösterilmektedir. Araştırmanın uyum indekslerine dair değer aralıkları Tablo 1'de sunulmuştur.

Tablo 1. Uyum İndeks Değer Aralıkları.

\begin{tabular}{|l|l|l|}
\hline İndeksler & İyi uyum & Kabul edilebilir \\
\hline CMIN/DF & $0 \leq \mathrm{x}^{2} / \mathrm{sd} \leq 2$ & $2 \leq \mathrm{x}^{2} / \mathrm{sd} \leq 5$ \\
\hline GFI &, $90 \leq$ &, $85 \leq \mathrm{GFI} \leq, 89$ \\
\hline AGFI &, $90 \leq$ &, $85 \leq \mathrm{AGFI} \leq, 89$ \\
\hline NFI &, $95 \leq$ &, $90 \leq \mathrm{NFI} \leq, 94$ \\
\hline IFI &, $95 \leq$ &, $90 \leq \mathrm{IFI} \leq, 94$ \\
\hline TLI &, $95 \leq$ &, $90 \leq \mathrm{TFI} \leq, 94$ \\
\hline CFI &, $95 \leq$ &, $90 \leq \mathrm{CFI} \leq, 95$ \\
\hline RMSEA & $\leq 0,5$ &, $06 \leq \mathrm{RMSEA} \leq, 08$ \\
\hline SRMR & $\leq 0,5$ &, $05 \leq \mathrm{SRMR} \leq, 10$ \\
\hline
\end{tabular}

Kaynak: Meydan ve Şeşen, 2011:37, İlhan ve Çetin, 2014:31

Şekil 2. Sinizm Ölçeği İkinci Düzey Doğrulayıcı Faktör Analizi Grafik Yapısı.

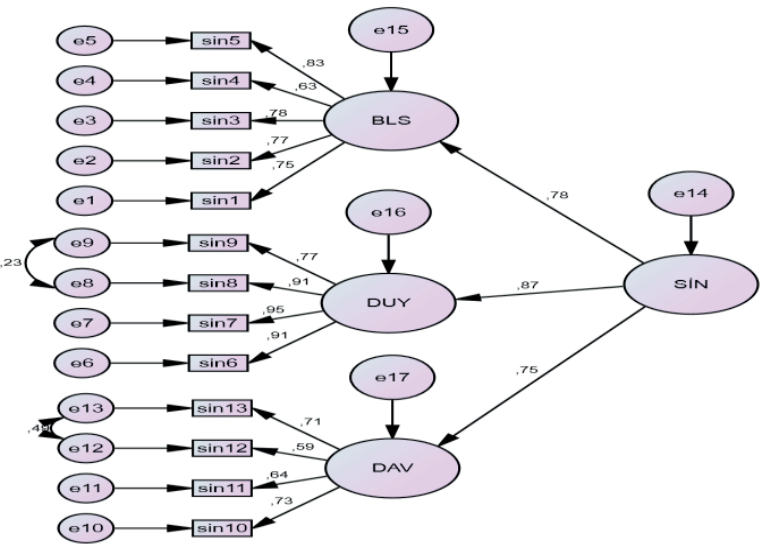


Tablo 1 incelendiğinde uyum indeks değerlerinin iyi değerlendirilebilecek değerler aldığı görülebilmektedir. Şekil 2'de araştırma kapsamındaki sinizm ölçeğinin faktör yapısını gösteren model maddelerinin faktör yükleri yer almaktadır.

22 maddelik tükenmişlik ölçeğine yapılan doğrulayıcı faktör analizi 3 boyutlu olarak sonuçlandırılmıştır. 22 maddeden oluşan tükenmişlik ölçeğinden 2 madde (21. ve 22 maddeler) faktör yükleri 0,50 değerinden düşük olduğundan dolayı analize dahil edilmemiştir.
Tablo 2.'de tükenmişlik ölçeğinin uyum indeksine dair değerler sunulmuştur.

İşte var olamama ölçeğine yapılan doğrulayıcı faktör analizi sonucunda 1 . ve 2 . Maddenin faktör yükleri 0,50 değerinden düşük olduğundan analizden çıkarılmıştır. Tablo 3'te işte var olamama ölçeğine ilişkin uyum indeksi değerleri gösterilmiştir. Tablodan da izlenebileceği gibi değerler kabul edilebilir sınırlar içerisindedir.

Tablo 2. Tükenmişlik Ölçeğine İlişkin DFA Uyum İndeksi Sonuçları.

\begin{tabular}{|l|l|}
\hline İndeks & Değer \\
\hline CMIN/DF & 1,967 \\
\hline GIF &, 929 \\
\hline AGFI &, 896 \\
\hline NFI &, 926 \\
\hline IFI &, 962 \\
\hline TLI &, 951 \\
\hline CIF &, 962 \\
\hline RMSEA &, 058 \\
\hline SRMR &, 052 \\
\hline
\end{tabular}

Şekil 3. Tükenmişlik Ölçeği Doğrulayıcı Faktör Analizi Grafik Yapısı.

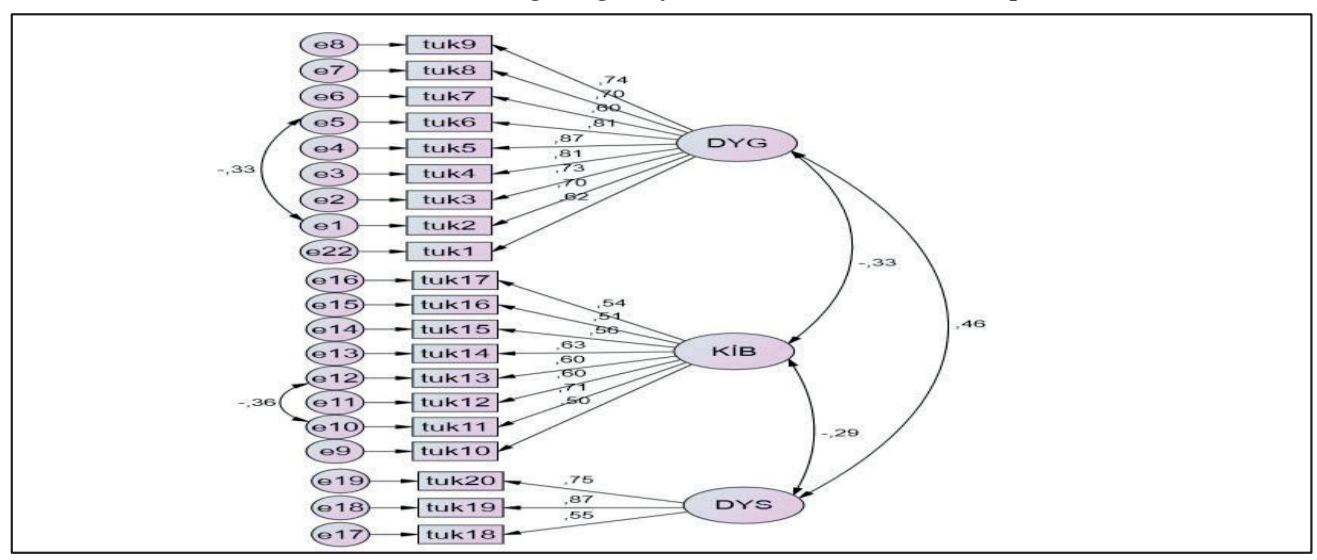

Tablo 3. İşte Var Olamama Ölçeğine İlişkin DFA Uyum İndeksi Sonuçları.

\begin{tabular}{|l|c|}
\hline İndeks & Değer \\
\hline CMIN/DF & 1,641 \\
\hline GFI &, 998 \\
\hline AGFI &, 982 \\
\hline NFI &, 995 \\
\hline IFI &, 998 \\
\hline TLI &, 987 \\
\hline CFI &, 998 \\
\hline RMSEA &, 042 \\
\hline SRMR &, 010 \\
\hline
\end{tabular}


Şekil 4. İşte Var Olamama Ölçeği Doğrulayıcı Faktör Analizi Grafik Yapısı.

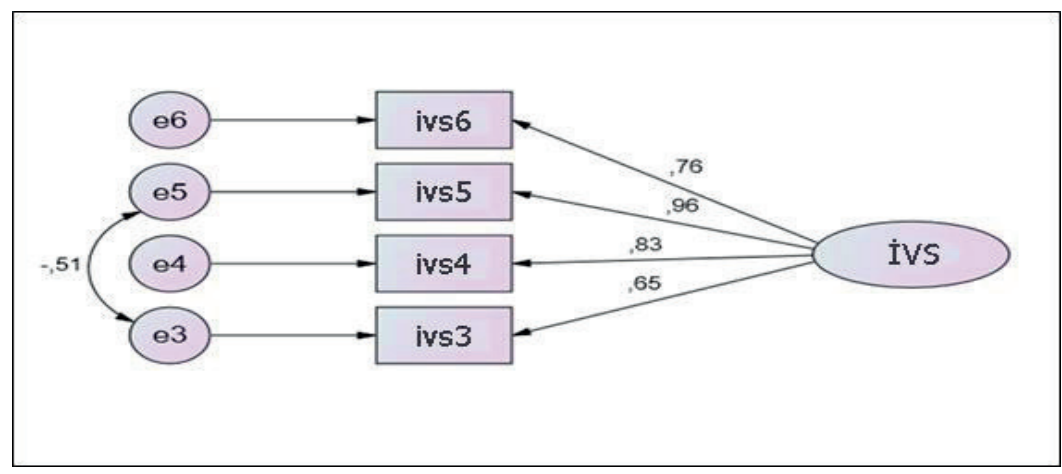

\subsubsection{Hipotez Testleri}

Çalışmanın hipotezlerini test etmek ve örgütsel sinizm, tükenmişlik ve işte var olamama arasındaki ilişkileri belirlemek amaciyla öncelikle korelasyon analizi yapılmıştır.

Tablo 4'de sinizm, tükenmişlik (duygusal tükenmişlik, kişisel başarı, duyarsızlaşma) ve işte var olamama arasındaki ilişkileri gösteren korelasyon katsayıları verilmektedir. Tablo incelendiğinde sinizmle işte var olamama ve tükenmişlik arasında anlamlı bir ilişkinin olduğu görülmektedir. Sinizmle işte var olamama $(\mathrm{r}=, 277)$ arasındaki ilişki sinizmin diğer bir değişken olan tükenmişlik ( $\mathrm{r}=482)$ ile olan ilişkisine oranla daha düşük düzeydedir.

Sinizm ile tükenmişliğin boyutlarından duygusal tükenmişlik $(\mathrm{r}=, 567)$, kişisel başarı hissi $(\mathrm{r}=-$,257) ve duyarsızlaşma $(\mathrm{r}=, 383)$ arasında \%99 seviyesinde anlamlı bir ilişki bulunmaktadır. Sinizmin duygusal tükenmişlik ve duyarsızlaşma ile ilişkisi pozitif yönlü iken, kişisel başarı hissi ile ilişkisi negatif yönlüdür. Buradan hareketle sinizmin duygusal tükenmişliği ve duyarsızlaşmayı artırdığı, kişisel başarı hissini ise azalttığ 1 ifade edilebilir.

İşte var olamama ile tükenmişliğin boyutlarından duygusal tükenmişlik ( $r=, 325)$, kişisel başarı hissi $(r=-, 155)$ ve duyarsızlaşma $(r=, 201)$ arasında \%99 seviyesinde anlamlı bir ilişki görülmektedir. İşte var olamamanın tükenmişliğin boyutlarından duygusal tükenmişlik ve duyarsızlaşma ile aynı yönlü, kişisel başarı ile ise ters yönlü bir ilişkinin varlığı söz konusudur. Bu durum örgütte yaşanan işte var olamama sorununun hemşirelerin duygusal tükenmişliklerini ve duyarsızlaşmalarını artıracağı kişisel başarı hislerini ise azaltacağ 1 şeklinde yorumlanabilir. İşte var olamama ile tükenmişlik $(r=, 279)$ arasında ise \%99 seviyesinde pozitif yönlü ve anlamlı bir ilişki vardır. Bu doğrultuda araştırmadaki hipotezlerden tüm hipotezlerin kabul edildiği ifade edilebilir. H4 ve alt hipotezlerin kısmi aracılık etkisinin varlığından söz edebiliriz.

\subsubsection{Yapısal Eşitlik Modelinin Analizi}

Araştırmaya konu olan değişkenlerin aralarındaki ilişkilerin istatistiksel açıdan anlamlı olup olmadığını belirlemek amacıyla yapısal eşitlik modelinden faydalanılmıştır. Bu amaçla kuramsal çerçeve doğrultusunda önceden belirlenmiş araştırmanın yapısal modeli AMOS paket programıyla analiz edilmiştir. Yapısal modelin geçerliliğini tespit etmek üzere uyum indeksi sonuçları göz önünde bulundurulmuştur. Araştırmaya ilişkin hipotezler doğrultusunda değişkenler arasındaki doğrudan ve dolaylı ilişkilerin anlamlılıkları incelenmiştir. Aracı etkiden söz edebilmek amacıyla eksojen (mediator değişken vasıtasıyla) endojen değişken üzerindeki dolaylı etkisinin anlamlılığını sınamak üzere bootstrap yöntemi kullanılmıştır. Bootstrap yöntemi, örneklem 1000 değerinde arttırılarak, güven aralıkları \%95 seviyesinde tutularak ve bootfaktör de-

Tablo 4. Korelasyon Analizi.

\begin{tabular}{|l|c|c|c|c|c|c|}
\hline $\begin{array}{l}\text { Boyutl } \\
\text { ar }\end{array}$ & SíN & IVS & DYG & Kï & DYS & UK T \\
\hline SíN & 1 & & & & & \\
\hline İVS &, $277^{* *}$ & 1 & & & & \\
\hline DYG &, $567^{* *}$ &, $325^{* *}$ & 1 & & & \\
\hline KiB &,$- 257^{* *}$ &,$- 155^{* *}$ &,$- 311^{* *}$ & 1 & & \\
\hline DYS &, $383^{* *}$ &, $201^{* *}$ &, $420^{* *}$ &,$- 269^{* *}$ & 1 & \\
\hline TUK &, $482^{* *}$ &, $279^{* *}$ &, $817^{* *}$ &, $149^{* *}$ &, $601^{* *}$ & 1 \\
\hline
\end{tabular}


ğeri 1 alınarak uygulanmıştır. Analizin ilk aşamasında aracı değişken modelden çıkarılarak bağımsız değişkenin bağımlı değişkenler üzerindeki etkisi araştırılmıştır. Akabinde aracı değişken modele dâhil edilerek bootstrap yöntemiyle aracı değişkenlerin etkileri ve anlam düzeyleri tespit edilmeye çalışılmıştır.

Literatürde tükenmişlik üç alt boyuttan, sinizm üç alt boyuttan işte var olamama ise tek boyuttan oluşmaktadır. Araştırmaya ilişkin yapısal model aşağıdaki gibidir.

Modelde DYG: Duygusal tükenmişlik, KİB: Kişisel başarı, DYS: Duyarsızlaşma, DAV: Davranışsal sinizm, DUY: Duyuşsal sinizm, BLS: Bilişsel sinizm, SİN: Sinizm, IVS: İşte var olamama, e: ilgili değişkenin hata varyansını ifade etmektedir. Şekil 5'te yer alan elipsler örtük değişkenleri (araştırma değişkenleri), dikdörtgenler gözlenen değişkenleri ve tek yönlü oklar bir değişkenin bir başka değişkene etkisini ifade ederken çift yönlü oklar değişkenler ve maddeler arasındaki ilişkileri temsil etmektedir. Literatüre uygun şekilde tükenmişlik üç alt boyuttan, sinizm üç alt boyuttan işte var olamama ise tek boyuttan oluşmaktadır. Araştırmaya ilişkin yapısal model şekil de gösterilmiştir.

Yapısal modelin test edilmesi ile uyum indeks sonuçları Tablo 5'de verilmektedir. Sonuçlar doğrultusunda uyum indeks sonuçlarının belirlenen referans aralık- larında olduğu görülmektedir.

\section{SONUÇ VE ÖNERILLER}

Araştırmada ilk olarak örgütsel sinizm ile tükenmişlik boyutları arasındaki ilişkinin anlamlılığı test edilmiştir. Elde edilen sonuçlara göre örgütsel sinizmin tükenmişliğin ilk boyutu olan duygusal tükenmeyi önemli ölçüde etkilediği belirlenmiştir. Buna göre hemşirelerin örgütsel sinizm düzeyi arttıkça duygusal tükenmeleri artmaktadır. Dolayısıyla örgütüne karşı olumsuz bir tutum içine giren hemşirelerin zamanla enerji kaybına uğramaları ve bunun neticesinde kendilerini güvensiz, bikkın ve yorgun hissetmeleri beklenmektedir. Örgütsel sinizm ve kişisel başarı hissi arasında ise negatif yönlü aynı zamanda istatistiki olarak anlamlı ilişki olduğu belirlenmiştir. Bu durum örgütteki olumsuz tutumların hemşirelerin bireysel başarılarını azalttığı şeklinde yorumlanabilir. Tükenmişliğin son boyutu olan duyarsızlaşma üzerinde örgütsel sinizmin etkisi ele alındığında örgütteki sinik tutumların artmasının hemşirelerin duyarsızlaşmalarını artırdığı sonucuna varılmıştır. Örgütte yaşanan olumsuz duygular ve tutumlar zamanla hemşirelerin örgüte karşı duyarsız davranışlar göstermesine neden olmaktadir.

Araştırmamızda ikinci olarak hemşirelerin yaşadığı örgütsel sinizmin işte var olamamaya neden olup olmadığı analiz edilmiştir. Sonuçlar araştırmaya katılan

Şekil 5. Araştırmanın Yapısal Modeline İlişkin Değişkenler Arasındaki Regresyon Katsayıları.

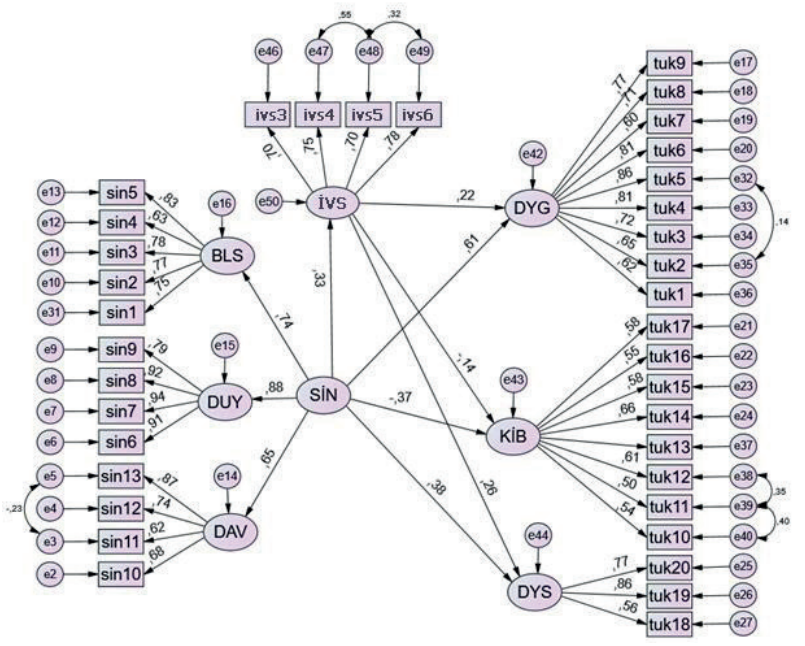

Tablo 5. Araştırma Modelinin Uyum İndeksi Sonuçları

\begin{tabular}{|l|l|}
\hline İndeks & Değer \\
\hline CMIN/DF & 2,040 \\
\hline GFI &, 844 \\
\hline CFI &, 914 \\
\hline IFI &, 914 \\
\hline RMSEA &, 055 \\
\hline SRMR &, 0713 \\
\hline
\end{tabular}


hemşirelerin sahip oldukları sinizm düzeylerinin işte var olamama sorunlarını artırdığını göstermektedir. Örgütte yaşanan çeşitli sıkıntılar (haksızlık, güvensizlik, iletişim) hemşirelerin işte var olamama sorunuyla karşı karşıya kalmalarına neden olmaktadır. Algılanan bu olumsuz atmosfer üzerlerinde strese ve motivasyon düşüklügüne sebep olmaktadır. Dolayısıyla bu durum sinik bireylerin işlerine kendilerini tam olarak verememesi ile sonuçlanmaktadır.

Üçüncü olarak hemşirelerin yaşadığı işte var olamama sorununun tükenmişliklerine etkisi incelenmiştir. İşte var olamama sorunu ile karşı karşıya kalan hemşirelerde duygusal tükenmişlik artarken, kişisel başarı azalmakta ve zaman içerisinde duyarsız davranışlar ortaya çıkmaktadır. Buna bağlı olarak işte var olamayan hemşireler zamanla duygusal olarak yıpranmakta, performansları azalmakta, katı davranmakta ve diğerlerine karşı kaba davranış eğilimleri göstermektedir.

Araştırmada son olarak örgütsel sinizmin tükenmişlik üzerine etkisinde işte var olamama sorununun aracılik etkisi belirlenmiştir. Elde edilen bulgulara göre örgütsel sinizmin tükenmişliğin tüm boyutları üzerine etkisinde işte var olamamanın kısmi aracılık etkisinin var olduğu tespit edilmiştir. Sinizmle tükenmişliği oluşturan faktörler arasında işte var olamamanın aracı rolü, duygusal tükenme ve duyarsızlaşma faktörlerinde kişisel başarı hissinin etkisine kıyasla çok daha belirgindir. Kişisel başarı hissi üzerinde anlamlı olsa da aracılık etkisinin derecesinin yüksek olmadığı tespit edilmiştir. Bu durum hemşirelerin işte var olamama sorunu yaşasalar dahi meslekleri gereği hastalarını anlayabilme, sorunları ile başa çıkabilme ve onlarla etkili iletişim kurabilmeleri gereğinden yola çıkarak kişisel başarılarının düşmediği şeklinde açıklanabilir. Ayrıca mesleğe adanmışlık, hemşirelerin eğitim, bilgi ve becerileri, profesyonel bakış açısı işte var olamama sorununun kişisel başarı hissini önemli ölçüde etkilememe nedenleri arasında sayılabilir. Örgütsel sinizmin çalışanların duygusal olarak yıpranmasına, kişisel başarılarının düşmesine ve zamanla duyarsız davranışlar göstermelerine neden olduğu belirlenmiştir. Örgütsel sinizm tükenmişliğe doğrudan etki ettiği gibi hemşirelerin işte var olamamasına yol açarak tükenmelerine de neden olmaktadır.

Çalışmada sinizmin tükenmişlik ve işte var olamamaya yol açmasına yönelik olarak elde edilen bulgulardan yola çıkarak; yöneticilere sinizme yol açan örgütsel faktörleri azaltmak amacıyla mesai saatlerinde esneklik ve motive edici prim sistemi gibi bir takım örgütsel düzenlemeler yapmaları, sinizmi azaltacak katılımcı yönetim biçimlerini tercih etmeleri önerilebilir. Ayrıca örgüt yönetimleri sinizme neden olan bireysel faktörleri azaltmak amacıyla hemşirelere psikolojik danışma hizmetleri sunabilir ya da işlerinin yoğunluğundan ötürü çocuklarına yeterince zaman ayırama- yan hemşirelerin çocuklarına kreş hizmeti sunabilir.

Bundan sonra yapılacak çalışmalarda farklı meslek gruplarında çalışanların yaşadıkları örgütsel sinizm, tükenmişlik ve işte var olamama durumları arasındaki ilişkiler SPSS, LISREL yöntemleri kullanılarak, aracılık ve doğrudan etkileri ile örgütsel yönetim şekillerinin farklılığ göz önünde bulundurularak incelenebilir.

\section{KAYNAKÇA}

AKHIGBE J. \& GAIL O. J. (2017). Job Burnout and Organizational Cynicism Among Employees in Nigerian Banks, European Scientific Journal August, 13 (22), 1857-7881.

ALAN, H. \& FIDANBOY, C. (2013). Sinizm, Tükenmişlik Ve Kişilik Arasındaki İlişkiler: Bilişiı Sektörü Çalışanları Kapsamında Bir İnceleme. Süleyman Demirel Üniversitesi Sosyal Bilimler Enstitüsü Dergisi, 26(0), 165-176.

AMASRALI, A. \& ASLAN, H. (2017). Ortaokul Ve Lise Matematik Öğretmenlerinin Örgütsel Sinizm İle Tükenmişlik Düzeyleri Arasındaki İlişsi. Mehmet Akif Ersoy Üniversitesi Eğitim Fakültesi Dergisi, 0(43), 64-92.

BALCI, O. (2016), İlköğretim Okullarinda Görev Yapan Öğretmenler Ve Yöneticilerin Örgütsel Sinizm, Kendini İşe Verememe (Presenteizm) Ve Sosyal Kaytarma Arasindaki İlişkinin İncelenmesi (Arnavutköy İlçesi Örneği). (Yayınlanmış Doktora Tezi), İstanbul: Arel Üniversitesi Sosyal Bilimler Enstitüsü.

BANG, H. \& REIO, T. (2017). Examining the role of cynicism in the relationships between burnout and employee behavior, Journal of Work and Organizational Psychology, 33 (3), 217-227.

BAYSAL, İ. A. (2012). Presenteeism (İşte Varolamama Sorunu) İle Örgütsel Bağlllık Arasındaki İlişki, Adnan Menderes Üniversitesi Akademik Personeli Üzerinde Bir Uygulama. (Yayımlanmış Yüksek Lisans Tezi). Aydın: Adnan Menderes Üniversitesi, Sosyal Bilimler Enstitüsü.

BÖLÜR, S. (2018). Algilanan Liderlik Davranışının Örgütsel Sinizm Ve Presenteizm Üzerine Etkisini Belirlemeye Yönelik Bir Araştırma. (Yayınlanmamış Yüksek Lisans Tezi). Edirne: Trakya Üniversitesi Sosyal Bilimler Enstitüsü İşletme Anabilim Dalı.

BURTON, WN. \& CONTI, DJ. (1999). The Real Measure Of Productivity, Bus Health, 17(11), 1999, 34-36.

BRANDES, P. (1997). Organizational Cynicism: Its Nature, Antecedents, and Consequences. (Dissertation of Doctor of Philosophy). Ohio: University of Cincinnati.

BRBOROVIC, O., BRUME , V., PAVLEKOVIC, G., \& MUSTAJBEGOVIC, J. (2014). Are Nurse Presenteeism And Patient Safety Culture Associated: A Cross-Sectional Study. Archives of Industrial Hygiene and Toxicology, 65:2, 149-156. https://doi. org/10.2478/10004-1254-65-2014-2462.

COOPER, C. \& CARTWRIGHT, S. (1994). Healthy Mind; Healthy 
Organization: A Proactive Approach to Occupational Stress, $\mathrm{Hu}$ man Relations, 47 (4), 455-470.

CORDES, CL \& DOUGHERTY, T.W. (1993). A review and an Integration of Research on Job Burnout, Academy of Management, Review, 18, 621-656. doi.org/10.5465/amr.1993.9402210153.

D'ABATE C.P. \& EDDY, E. R. (2007). Engaging in Personal on the Job: Extending the Presenteeism Construct, Human Resource Development Quarterly,18 (3), 361-383.

DEAN, W., BRANDES, J., PAMELA \& DHARW ADKAR, R. (1998). Organizational cynicism, The Academy of Management Review, 23 (2), 341-352.

DEMEROUTI, E., LE BLANC, P. M., BAKKER, A. B., SCHAUFELI, W. B. \& HOX, J. (2009). Present But Sick: A Three-Wave Study on Job Demands, Presenteeism and Burnout. Career Development International, 14(1), 50-68.

DURU, E., DURU, S. \& BALKIS, M. (2014). Analysis of relationships among burnout, academic achievement, and self-regulation. Educational Sciences: Theory \& Practice, 14(4), 1274-1284.

ERYEŞIL, K. \& ÖZTÜRK, M. (2016). The Relationship Between Organizational Cynicism And Burnout: A Field Research İn Health Sector, See discussions, stats, and author profiles for this publication at: https://www.researchgate.net/publication/ 309611239, ResearchGate.

FERREIRA, A. \& MARTINEZ L. (2012). Presenteeism And Burnout Among Teachers İn Public And Private Portuguese Elementary Schools, The International Journal of Human Resource Management, 23 (20), 4380-4390.

FREUDENBERG ER, H. J. (1974). Staff Burnout, Journal of Social Issue, 30, 159-165.

GÜN, F., (2015). Öğretim Elemanlarının Algllarına Göre Örgütsel Sinizm İle Tükenmişlik Düzeyleri Arasındaki İlişkinin İncelenmesi. (Yayınlanmış Yüksek Lisans Tezi), Ankara: Hacettepe Üniversitesi Sosyal Bilimler Enstitüsü.

GÜRBÜZ, H. \& BAYRAMLI, Ü. Ü. (2005). Eskişehir İli Yönetici Sekreterlerinin Tükenmişlik Düzeylerini Belirleme Ölçeği, Günümüz İş Ortamında Büro Yönetimi ve Sekreterlik IV. Ulusal Büro Yönetimi Ve Sekreterlik Kongresi, 143-162, Ankara.

HAIR, J. F., ANDERSON, R. E., TATHAM, R., L., \& BLACK, W. C. (1998). Multivariate Data Analysis (Fifth edition). United States: Prentice-Hall, Inc.

HEMP, P. (2004). Presenteeism: At Work: But Out of It. Harvard Business Review, 82, 49-58.

IACOBUCCI, D. (2010). Structural Equations Modeling: Fit İndices, Sample Size, And Advanced Topics. Journal of Consumer Psychology, 20(1), 90-98.

HOCK, R. ( 1988). Professional Burnout Among Public School Teachers, Public Management, 17 (2), 167-189.

İBRAHIM AĞAOĞLU, Ö. \& CAN, E. (2017). Örgütsel Sinizm ile Örgütsel Tükenmişlik Arasındaki İlişkinin İncelenmesi: Hizmet Sektörü Çalışanları Üzerine Ampirik Bir Araştırma. Yıldız Sosyal Bilimler Enstitüsü Dergisi, 1 (2), 181-205.
İNCESU, E., YORULMAZ, M. \& EViRGEN, H. (2017). Örgütsel Sinizmin Tükenmişlik Üzerine Etkisi: Hastane Çalışanları Üzerine Bir Araştırma. Uluslararası Sağllk Yönetimi Ve Stratejileri Araştırma Dergisi, 3 (3), 370-380.

JAMES, M. S. L. (2005). Antecedents And Consequences Of Cynicism In Organizations: An Examınation of The Potential Positive And Negative Effects On School System. Dissertation Submitted to the Department of Management in Partial Fulfillment of the Requirements for the Degree of Doctor of Philosophy Degree Awarded, Florida: The Florida State University, Spring Semester, 2005.

JOHNSON, J. L. \& O'LEARY-KELLY, A. M. (2003). The Effects Of Psychological Contract Breach And Organizational Cynicism: Not All Social Exchange Violations Are Created Equal. Journal of Organizational Behavior. 24, 627-647.

KALAĞAN , G. (2009). Araştırma Görevlerinin Örgütsel Destek Algılart ile Örgütsel Sinizm Tutumları Arasındaki İlişki. (Yayınlanmamış Yüksek Lisans Tezi). Antalya: Akdeniz Üniversitesi, Sosyal Bilimler Enstitüsü.

KLINE, R.B. (2016). Principles and Practice of Structural Equation Modeling. New York: The Guilford Press.

KÖSE, Ö. (2019). Presenteeism (İște var olamama) ile Örgütsel Özdeşleşme ve Tükenmişlik Arasındaki İlişkinin Analizi, (Yayımlanmış Yüksek Lisans Tezi), İstanbul: Sabahattin Zaim Üniversitesi Sosyal Bilimler Üniversitesi.

LOWE G. (2012). Here İn Body, Absent in Productivity: Presenteeism Hurts Output, Quality Of Work-Life and Employee Health. Canadian HR Reporter, the National Journal of Human Resource Management, 12, 9-10.

MASLACH, C. \& JACKSON, S. E. (1981). The Measurement of Experienced Burnout. Journal of Occupational Behavior, 2, 99113.

MASLACH, C., MICHEAL P. \& LEITER. (1997). The Truth About Burnout, San Francisco,CA: Jossey-Bass.

MASLACH, C., SCHAUFELI W. \& LEITER, P. (2001). Job Burnout, Annual Review of Psychology, 52, 397-422.

MASLACH, C. \& ZIMBARDO, P., G. (1982). Burnout- The cost of Caring. New Jersey: Prentice Hall, Inc., New Jersey: Englewood Cliffs.

MEYDAN, C. H. \& ŞEŞE, H. (2011). Yapısal eşitlik modellemesi AMOS uygulamaları. Ankara: Detay Yayıncılık.

MUNIR, F., Y ARKER, J. \& HASLAM, C. (2008). Sickness Absence Management: Encouraging Attendance or Risk-Taking Presenteeism in Employees with Chronic Illness?, Disability and Rehabilitation, 30 (19), 1461-1472.

ÖZDEMIR, Ö. \& YAŞAR, O. (2016). The Relationship Of Organizational Cynicism, Burnout, And Organizational Commitment: A Study On Middle School Teachers, Eurasian Academy of Sciences Eurasian Business \& Economics Journal, 6, 50-61.

ÖZLER, DE. \& ATALAY, C. G. (2011). A Research To Determine The Relationship Between Organizational Cynicism And Burnout Levels Of Employees İn Health Sector. Business And Management Review, 1(4), 26-38. 
PINES, AM. \& ARONSO, E. (1988). Career Burnout (Causes and Cures). The Free Press, New York: A Division of Macmillan, Inc.

SIMHA, A., ELLOY, D. F., HUANG \& HAN-CHUNG, (2014), The moderated relationship between job burnout and organizational cynicism, Management Decision, 52 (3), 482-504.

ŞİMŞEK, Ö. F. (2007). Yapısal Eşitlik Modellemesine Giriş, Temel İlkeler ve LİSREL Uygulamaları. Ankara: Ekinoks.

SOYSAL, A. (2009). "Çalışanlarda Tükenmişlik Düzeyinin Bazı Demografik Değişkenler Açısından İncelenmesi: Kahraman Maraş Emniyet Müdürlüğü'nde Bir Araştırma”, VII. Kamu Yönetimi Forumu (KAYFOR) 2. Kitap, 290-309.

ÜÇOK, I., D. (2012). Sinik Tutum Ve Psikolojik Sözleşme İhlali Algısının Tükenmişlik Üzerindeki Etkisi. (Yayınlanmış Yüksek Lisans Tezi), İstanbul: Marmara Üniversitesi Sosyal Bilimler Enstitüsü.

WEI, WANG, (2015), Exploring The Relations Between Student Cynicism And Student Burnout, Psychological Reports: Employment Psychology \& Marketing, 117 (1), 103-115.

WRIGHT, T. A. \& DOUGLAS, B. G. (1998). The Contribution of Burnout to Work Performance, Journal Of Organization Behavior, 18 (5), 491-499.

YAVAN, Ö. (2017). Çalıșanların ișe gitmeme ile varmıș ve çalışıyormuş gibi yapma eğilimlerinin incelenmesi: Zonguldak Türkiye Taşkömürü Kurumu Örneği. International Journal of Economic and Administrative Studies, 19, 249- 276.

YILDIRIM, M.H., SAYGIN, M. \& UGUZ, Ş. (2013). Effects Of Presenteeism Syndrome On Employees Burnout Levels. Internatiomal Journal Of Sciences And Humanity Studies, 6 (1), 1-10.

ZENGIN, Y. \& KAYGIN, E.(2016). Tükenmişlik Sendromu ile Presenteeism (İşte Var Ol(ama)ma) Arasındaki İlişkinin İncelenmesi: Kars SGK Örneği. Eurasian Academy of Sciences Social Sciences Journal, 1, 487-500. 